DOI: $10.17805 / z p u .2015 .2 .27$

\title{
Сонет 130 У.Шекспира в переводах на русский и белорусский языки: общее и специфическое
}

\author{
И. А. ХОРСУН
}

(ГОМЕЛЬСКИЙ ГОСУДАРСТВЕННЫЙ УНИВЕРСИТЕТ ИМЕНИ Ф. СКОРИНЫ, БЕЛАРУСЬ)

Проблемным полем данной статьи выступает сложность переводного процесса с неблизкородственных языков (в частности, с английского на русский и белорусский языки): различия в способах организации стихотворной речи; количественно-качественные расхождения метрических средств и поэтические особенности.

В статье автор проводит подробный лингвистический анализ оригинала сонета 130 У. Шекспира в сравнении и сопоставлении переводов В. Н. Дубовки и С. Я. Маршака (общее содержание, идея сонета, особенности передачи рифмы, акцентной структуры сонета), на примере которого показывает мастерство каждого из переводчиков в адекватной передаче всей картины сонета.

В сравнительной таблице приведены стилистические средства (сравнения, эпитеты), используемые белорусским и русским переводчиками для создания образов рассматриваемого сонета. Автор анализирует степень соответствия выбранных ими средств, несмотря на разный характер языков переводов и языка оригинала.

Переводы на белорусский и русский языки сонетов Шекспира, выполненные В. Н. Дубовкой и С. Я. Маршаком, свидетельствуют о зрелости национальных школ художественного перевода в Беларуси и России, а сами переводы становятся образцами для последующих поколений переводчиков.

Ключевые слова: У. Шекспир, С. Маршак, В. Дубовка, сонет, сонеты Шекспира, теория перевода, переводной процесс, отдаленно родственные языки, поэтические особенности, рифма, акцентная структура, сравнение, эпитет.

\section{BВЕАЕНИЕ}

Dеализация задач по освоению наследия великого английского драматурга У. Шекс1 пира русским и белорусским литературным контекстом не могло произойти без тщательной переводческой работы, внешне незаметной, но такой кропотливой. Особенно сложной данная задача представляется для белорусской переводческой школы, 
которая, по словам Н. Н. Воинова, даже сегодня все еще продолжает формирование (Воінаў, 1998: 58-63). С одной стороны, проблема состоит в сложностях переводного процесса с неблизкородственных языков: различия в способах организации стихотворной речи, количественно-качественные расхождения метрических средств и поэтические особенности. Это обусловлено тем, что белорусский и русский - языки синтетические (слова соединяются при помощи флексий - окончаний) - противостоят английскому, аналитическому (слово - передатчик только лексического значения, а грамматическое значение оформляется отдельно: порядком слов, служебными словами, интонацией). Поэтому, опираясь на общую теорию перевода, можно с уверенностью утверждать, что средства достижения соответствующего художественного эффекта будут разными в отдаленно родственных языках. С другой стороны, при переводе оригинальных произведений переводчик должен прежде всего сохранять дух оригинала, переводить стилями, что невозможно без совершенного знания не только языка, но и времени, условий жизни творца.

Сонеты Уильяма Шекспира полностью переведены на белорусский язык Владимиром Аубовкой (изд. 1964) и на русский язык, среди прочих, Самуилом Маршаком (изд. 1949). Переводы С. Маршака стали эталоном для современников и последователей. Переводческая практика В. Аубовки, который получил серьезное образование в России, владел английским языком, внесла в белорусскую традицию перевода особый вклад. Его книга «Санеты» подтверждает самостоятельное развитие национальной традиции белорусских переводчиков.

В. Небышинец справедливо писал, что «перед Аубовкой наша литература в большом долгу за его подлинные образцы переводческого мастерства, где гармонично сочетаются высокая поэзия и строгое соответствие оригиналу во всех его идейно-художественных компонентах» (пер. мой. - И. Х.) (Небышынец, 1986: 261-270).

Эти слова подтверждает подробный лингвистический анализ оригинала сонета 130 в сравнении и сопоставлении переводов Аубовки и Маршака.

Общее содержание и идея сонета передаются в переводах адекватно: возлюбленная поэта, хотя и совсем земная, и не очень красивая, самая дорогая для него.

My mistress' eyes are notbing like the sun;

Coral is far more red than her lips' red;

If snow be white, why then her breasts are dun;

If hairs be wires, black wires grow on her head

(курсив мой. - И. Х.) (Shakespeare's Sonnets, 1997: 375).

Перевод первого катрена В. Аубовки и С. Маршака позволяет подчеркнуть специфику подхода к восстановлению образа в близкородственных, но отличающихся языках:

Аа зорак не падобны любай вочы,

Каралі - шмат за вусны чырваней,

Не златакосая - пад колер ночы,

А снег - бялей смугі яе грудзей

Ее глаза на звезды не похожи,

(Шэкспір, 1964: 134).

Нельзя уста кораллами назвать,

Не белоснежна плеч открытых кожа,

И черной проволокой вьется прядь

(Шекспир, 1949: 584). 


\section{ОСОБЕННОСТИ РИТМИКИ И РИФМОВКИ}

Каждую отдельную строку сонета составляют четыре ударных слова, которые и объединяют четыре акцентные группы в строке. Так, акцентная структура первой строки в оригинале выглядит так: $\mathrm{O}--/ \mathrm{O}-/ \mathrm{O}-/-\mathrm{O}^{1}$ (10 слогов), в белорусском и русском варианте их 11, что объясняется двухслоговой структурой местоимений яе, ее и окончаниями -ая (златакосая), -ет (cmynaеm). При произношении они могут редуцироваться, но тем не менее являются двусложными.

Количество слогов и акцентных групп во второй и четвертой строках совпадает как в русском, так и в белорусском вариантах перевода.

Однако «интонационное» внимание привлекает третья строка первого катрена, в которой акцентных групп пять $(-\mathrm{O} /-\mathrm{O} / \mathrm{O}-/-\mathrm{O} /-\mathrm{O})$. В. Аубовка строит перевод первого катрена исключительно по акцентной структуре, состоящей из четырех групп.

В русском переводе вариативность наблюдается в десятой строке, которая имеет следующую акцентную структуру: $-\mathrm{O}---/ \mathrm{O}-/--\mathrm{O}$.

That music hath a far more pleasing sound (4)

(Shakespeare's Sonnets, 1997: 375).

Аы ўцехі больш мне музыка нясе (4)

Особенного света на челе (3)

(Шэкспір, 1964: 134).

(Шекспир, 1949: 584).

В оригинале сонет построен на мужской рифме. В переводах наблюдаем чередование женской и мужской рифм (нечетная/четная строки), две последние строки имеют женскую рифму. Полное совпадение женской рифмы в русском (едва ди - оболгали) и белорусском (Вочь - ночь) вариантах перевода единично, полное совпадение мужской рифмы наблюдается в белорусском тексте. У Шекспира рифмуются два последних звука слова.

Таким образом, получается одинаковая картина: полных рифм - четыре, неполных - три; женских - четыре, мужских - три.

Несовпадение с оригиналом можно объяснить различным характером акцентной структуры английских, белорусских и русских слов. Как известно, в славянских языках флексии обусловливают акцентную структуру слова, и количество слов со структурой «ударный + неударный» преобладает в славянских языках (Метлюк, 1982: 59).

\section{ОСОБЕННОСТИ ИСПОАЬЗОВАНИЯ СТИАИСТИЧЕСКИХ СРЕАСТВ}

Главная тема сонета, раскрываемая посредством образов, - возлюбленная, глаза которой Шекспир сравнивает со звездами (the sun - coлние - это большая звезда), губы - с кораллами.

Сравнения, используемые переводчиками В. Аубовкой и С. Маршаком, совпадают с оригиналом, но вторую строку белорусского перевода можно считать более адекватной (сохраняется троп).

Каралі - шмат за вусны чырваней

Нельзя уста кораллами назвать

Coral is far more red than her lips' red (Шэкспір, 1964: 134). (Шекспир, 1949: 584). (Shakespeare's Sonnets, 1997: 375). 
Развитие образа любимой У. Шекспир продолжает сравнением цвета кожи со снегом, а волосы - с черной проволокой. В белорусском переводе снег тоже бялей смугі яе грудзей, а вот валасы - чорныья, як ноч, но нигде не упоминается об их жесткости. У С. Маршака плечи не белоснежные, а волосы вьются черной проволокой.

В следующих двух строках Шекспир вспоминает дамасские розы (красные и белые) и подчеркивает, что даже и следа нет от их цвета на щеках его любимой. Аубовка сохраняет только дамаскія ружы и добавляет еще «рукі», вероятно, для рифмы. На наш взгляд, здесь перевод Маршака более точный:

С дамасской розой, алой или белой,

Нельзя сравнить оттенок этих щек

(Шекспир, 1949: 584).

Говоря о дыхании любимой, Шекспир пишет, что нельзя сравнить ее дыхание с волшебным ароматом. У Аубовки краскі имеют более приятный запах, а у Маршака фиалки пахнут лучше, чем ее тело. Таким образом, восприятие красоты через запах передается несколько иными средствами (perfumes - краскі - фиалки), хотя целостность образа в целом сохраняется.

Голос любимой звучит совсем не так, как музыка, о чем говорят следующие две строки. В переводе Аубовки сравнение производится с музыкой, в то время как в русском варианте речь идет о совершенных линиях и свете на челе (совсем иной образ).

В строках 11 и 12 Шекспир рассказывает о фигуре и походке женщины, которой очень далеко до небожительницы. Аревние говорили, что богиню узнаешь по походке (Et vera incessu patuit dea), а возлюбленная Шекспира просто ходит по земле. У Аубовки любимая ходзіщь зусім звычайна (снижается стилистическое значение глагола tread). Маршак дает два слова - богини ществуют, а она ступает, что, по нашему мнению, верно подчеркивает контраст.

В заключительных строках сонета У. Шекспир клянется, что его любовь - исключительно особенная и безмерная: ее не сравнить с той, которая описывается в сонетах, где любимые - неземные существа. В. Аубовка передает клятву в несколько другом стиле: нигде нет лучших кабеиін, но не упоминает о том, что сонет У. Шекспира отличается от общепринятых сонетов, в которых любимая была обязательно красавицей. С. Маршак переводит последние строки более точной рифмой.

И все ж она уступит тем едва ли,

Кого в сравненьях пышных оболгали

(Шекспир, 1949: 584).

Поскольку рассматриваемый сонет описывает и характеризует возлюбленную автора, раскрывая образ в большей степени через эпитеты и сравнения, проведем сравнительный анализ данных приемов в переводах.

$$
\begin{aligned}
& \text { eyes - sun } \\
& \text { lips - coral } \\
& \text { breasts - snow } \\
& \text { hairs - wires } \\
& \text { cheeks - roses } \\
& \text { breath - perfumes } \\
& \text { speech - music } \\
& \text { goddess go(es) }
\end{aligned}
$$

$$
\begin{aligned}
& \text { глаза - звезды }++ \\
& \text { уста - кораллы }++ \\
& \text { плечи - снег }+ \\
& \text { прядь - проволока }++ \\
& \text { щеки - розы }++ \\
& \text { тело - фиалка - } \\
& \text { чело - свет - } \\
& \text { богини шествуют }+
\end{aligned}
$$


treads

звычайная хада -

она ступает +

she - false compare

яна - іншыя кабеты +

она - другие +

( «++» означает полное совпадение, «+» частичное, «一» отсутствие совпадения).

Насыщенность полных соответствий сравнений в переводах наблюдается в начале сонета, далее переводчики позволяют себе вольность замены, компенсации, оставляя смысловые слова, важные в конкретном сонете, без должного эквивалента.

red lips

white snow

dun breasts

black wires

damask

(red white) roses

delightful perfumes

pleasing music

rare love

false compare

чырвоныя вусны ++
белы снег ++
смуглыя грудзі ++
колер ночы +
дамаскія ружы +
прыемны водар ++
уцешная музыка ++
над яе няма +
VV

чырвоныя вусны ++

белы снег ++

смуглыя грудзі ++

колер ночы +

VV
белоснежна ++
VV
черная проволока ++
дамасская
(алая белая) роза ++
нежная фиалка +
VV
уступит VV
оболгали +

( «++» означает полное совпадение, «+» частичное, «VV»- отсутствие передачи).

Общий подсчет показывает, что в белорусском переводе больше точных соответствий, отсутствие соответствий встречается только в одном случае, в то время как в русском варианте - их четыре (особенно в эпитетах).

В целом сонет в обоих переводах звучит естественно и передает смысл оригинала. В. Аубовка рисует любимую Шекспира даже немного красивее, чем ее описывает автор (например, reeks - несет некрасивый запах, в переводе - духмяные bусны, хотя и не такие как кветкі-краскі; волосы черные как ноч, не жесткие как $\partial p o m)$, но словом кабечін он возвращает читателю образ совсем обычной женщины. Перевод С. Маршака звучит стилистически более возвышенно за счет таких слов как чело, совершенные линии, шествовать, пьшные сравненья.

\section{ВЫВОАЫ}

Подводя итоги, отметим, что в русском и белорусском вариантах переводчики сохраняют дух оригинала сонета благодаря точно подобранной рифме, взаимодействию тропов (эпитетов, сравнений), используемых в детальном создании главного образа сонета - «возлюбленной»У. Шекспира. Талантливый поэт и переводчик В. Аубовка подтвердил, что белорусское поэтическое слово сохраняет большую силу творческого вдохновения великого английского поэта, искренность открыто высказанного чувства, мощность художественного проникновения в тайную суть.

\section{ПРИМЕЧАНИЕ}

1 Акцентная структура, О - ударный слог, «-»- неударный.

\section{СПИСОК АИТЕРАТУРЫ}

Метлюк, А. А. (1982) Просодия белорусского языка в условиях двуязычия. Минск : Изд-во Минск. гос. пеА. ин-та иностр. языков. 106 с.

Шекспир, В. (1949) Сонеты / пер. С. Я. Маршака // Шекспир В. Полн. собр. соч. : в 8 т. / под ред. А. А. Смирнова. М. ; $\Lambda$. : Гослитиздат. Т. 8. С. 517-596. 
Воінаў, М. М. (1998) Плён супольнасці: Мастацкі пераклад і развіццё беларускай літаратуры на памежжы XIX-XX стагоддзяў. Мінск : Беларуская навука. 200 с. (На белор. яз.).

Небышынец, В. (1986) Ступень адказнасці. Мінск : Мастацкая літаратура. 335 с. (На белор. яз.).

Шэкспір, У. (1964) Санеты / пер. У. Аубоўка. Мінск : Беларусь. 163 с. (На белор. яз.).

Shakespeare's Sonnets (1997) / ed. by K. Duncan-Jones. L. : Arden Shakespeare. 488 p.

Дата поступления: 5.02.2015 2.

\section{SONNET 130 BY WILLIAM SHAKESPEARE TRANSLATED INTO RUSSIAN \\ AND BELARUSIAN: THE GENERAL AND THE SPECIFIC \\ I. A. KHORSUN \\ (F. SKoRINA Gomel State UNIVERSITY, BeLARUS)}

The problem field of this paper lies in the complexity of the translation between only distantly related languages (in particular, from English into Russian and Belarusian): the differences in the way of the organization of poetic speech, quantitative and qualitative differences of metric tools, and poetic features.

The author has carried out a detailed linguistic analysis of the original of sonnet 130 by Shakespeare in comparison with Vladimir N. Dubovka's and Samuil Ya. Marshak's translations (poetic content, the idea of the sonnet, the peculiarities of rhyme and the accent structure of the sonnet). It shows the peculiar skills of each translator in adequate rendering of the whole entity of the sonnet.

The comparative table shows the stylistic devices (similes, epithets) used by the Belarusian and Russian translators to create the images in the sonnet. The author analyzes the degree of compliance with the original in the devices chosen by the translators, despite the synthetic nature of Russian and Belarusian in contrast to the analytic nature of the original language (English).

The translations of Shakespeare's sonnets into Belarusian and Russian by Vladimir N. Dubovka and Samuil Ya. Marshak testify to the maturity of the national schools of literary translation in both Belarus and Russia, while their texts have been viewed as models by subsequent generations of interpreters.

Keywords: W. Shakespeare, S. Marshak, V. Dubovka, sonnet, Shakespeare's sonnets, translation theory, translation process, distantly related languages, poetic features, rhyme, accent structure, simile, epithet.

\section{REFERENCES}

Metliuk, A. A. (1982) Prosodiia belorusskogo iazyka v usloviiakh dvuiazychiia [Prosody of the Belarusian language under the conditions of bilingualism]. Minsk, Minsk State Pedagogical Institute of Foreign Languages Publ. 106 p. Pp. 59-60. (In Russ.).

Shakespeare, W. (1949) Sonety [Sonnets]/ transl. by S. Ya. Marshak. In: Shakespeare, W. Polnoe sobranie sochinenii [Complete works] : in 8 vols. / ed. by A. A. Smirnov. Moscow ; Leningrad, Goslitizdat Publ. Vol. 8. Pp. 517-596. (In Russ.).

Voinaw, M. M. (1998) Plion supol'nastsi: Mastatski peraklad i razvitsio belaruskai litaratury na pamezhzhy XIX-XX stagoddziaw [Fruits of the community: Literary translation and the development of Belarusian literature in the $19^{\text {th }}-20^{\text {th }}$ centuries]. Minsk, Belaruskaia Navuka Publ. 200 p. (In Belarusian).

Nebyshynets, V. (1986) Stupen' adkaznastsi [Degree of responsibility]. Minsk, Mastatskaia Litaratura Publ. 335 p. (In Belarusian).

Shakespeare, W. (1964) Sanety [Sonnets]/ transl. by V. Dubovka. Minsk, Belarus' Publ. 163 p. (In Belarusian).

Shakespeare's Sonnets (1997) / ed. by K. Duncan-Jones. London, Arden Shakespeare. 488 p. 
Хорсун Ирина Александровна - аспирант кафедры белорусской литературы Гомельского государственного университета имени Ф. Скорины. Адрес: 246019, Беларусь, г. Гомель, ул. Советская, д. 108. Тел.: +375 (232) 60-32-40. Эл. адреc: belitchair@gsu.by. Научный руководитель А-р филол. наук, проф. И. Ф. Штейнер.

Khorsun Irina Aleksandrovna, Postgraduate Student, Department of Belarusian Literature, F. Skorina Gomel State University. Postal address: 108 Sovetskaya St., 246019 Gomel, Belarus. Tel.: +375 (232) 60-32-40. E-mail: belitchair@gsu.by. Research adviser: I. F. Shteiner, Doctor of Philology, Professor. 